The book is fairly short (267 pages) and has the merit of being easy to read. Resident anaesthetists and ear, nose and throat house surgeons should find much valuable information in it.

$$
\text { C.C.C. }
$$

\section{AN INTRODUCTION TO EXPERIMENTAL SURGICAL STUDIES}

By W. J. Dempster, F.R.C.S. Pp. 463, with $7 \mathrm{r}$ illustrations. Oxford: Blackwell Scientific Publications. 1957. 50s.

With the present day development of surgery as a science there has been a great increase in experimental surgery, both as a means of inquiry into the pathogenesis of a variety of disorders and for the detection and solution of problems in new surgical techniques prior to human application. The author of this book attempts to provide for the younger surgeon a wide range of references and a critical commentary in this field.

The sections on wound healing, organ and tissue transplantation and genito-urinary problems occupy over half the book and are on the whole sound and comprehensive. In other fields discussed with which the author is perhaps less familiar the test is not so reliable. The lack of reference under the heading of heart-lung substitutes to the modern Gibbon machine, in practice probably the most successful, is most notable and it is doubtful if vascular surgeons would accept the statement that they have abandoned the use of homografts in favour of nylon substitutes.

A few such imperfections are to be expected in any new book of this scope and do not detract from its value as a reference source to those engaged in experimental surgery.

\section{J.L.}

\section{CHEMICAL METHODS IN CLINICAL MEDICINE}

By G. A. Harrison, M.D., F.R.I.C. Fourth Edition. Pp. 667, figs. 158. London: J. \& A. Churchill Ltd. 65 s.

Ten years have elapsed since the last edition of this standard work appeared. Dr. Harrison has added a great deal of new material but managed to compress it into few extra pages. There are welcome new accounts of photoelectric absorptiometers and of the flame photometer (it is a pity that the author still clings to milligrams in describing sodium and potassium standards). Chromatography and electrophoresis are described. The author's prejudice against the estimation of the 17 -Ketosteroids in urine seems hard to justify. Here and there certain changes of fashion might have led to changes of emphasis: few clinicians now bother with the urea concentration test for example, while PSP excretion, which is dismissed in three lines, is estimated in most American laboratories. The author's views on diabetes are unorthodox: it is surprising to find that mild diabetics should either be warned not to lose weight (p. 193) or told to maintain it (p. 194) when a large number of obese patients with glycosuria regain normal carbohydrate tolerance when weight is reduced, a fact which is not mentioned. The section on diabetic coma is valueless and would be better omitted. There is a short section on intravenous fluids; it might with advantage include some notes on potassium therapy; the author's only reference to a paper on postoperative fluid and electrolyte therapy is dated 1938 . The section on liver function tests is more topical, but most workers would like to see a description of the thymol turbidity test included, though the author appears to have no use for it.

These shortcomings do not detract from the value of the book as a whole. Comprehensive andclearly written, beautifully produced and inexpensive, it must remain a necessary standby in every routine laboratory.

\section{THE MAMMALIAN CEREBRAL CORTEX}

By B. Delisle Burns, B.A., M.R.C.S., L.R.C.P. Pp. vii + II9, with 24 diagrams. London: Edward Arnold Ltd. I958. 2 is.

This book, which is the fifth of the recent series of Monographs by the Physiological Society, is slightly unfortunately named. The work reviewedo and described is mainly concerned with the isolatedo cerebral cortex, which means that a piece of cortex $20 \mathrm{~mm}$. long and $5 \mathrm{~mm}$. wide and $4 \mathrm{~mm}$. deep is studied in an animal that has already been decerebrated at the level of the tentorium. While Dr. Delisle Burns does not confine himself in his discussion to this preparation he is mainly concerned with results arising from this.

It should be stated, however, that the book is extremely clear. The author does not try and hide our present ignorance behind a barrage of technology and while he discusses memory and other difficult subjects, he tries to base his argument on the results which are available and is in search, as he says, of 'the cellular machinery of memory.'

Within these limitations the reviewer would strongly recommend this book to neurologists who are trying to come to grips with this most difficult part of their subject.

\section{STEDMAN'S MEDICAL DICTIONARY}

Edited by N. B. TAYlOR, V.D., M.D., F.R.C.S., F.R.C.P. Nineteenth edition. Pp. xlvi + I,656, illustrated. London: Baillière, Tindall $\&$ Cox Ltd. I 957 . 88s.

The nineteenth edition maintains the standard of that of 1954 , with the inevitable addition of several thousand new medical terms and a hundred pages. Two of the outstanding features of this dictionary are the section on medical etymology and the 